\title{
Front Matter: Volume 9519
}

, "Front Matter: Volume 9519," Proc. SPIE 9519, Nanotechnology VII, 951901 (26 June 2015); doi: 10.1117/12.2203113

SPIE. Event: SPIE Microtechnologies, 2015, Barcelona, Spain 


\title{
PROCEEDINGS OF SPIE
}

\section{Nanotechnology VII}

\section{Ion M. Tiginyanu}

Editor

\author{
4-6 May 2015 \\ Barcelona, Spain \\ Sponsored and Published by \\ SPIE
}


The papers included in this volume were part of the technical conference cited on the cover and title page. Papers were selected and subject to review by the editors and conference program committee. Some conference presentations may not be available for publication. The papers published in these proceedings reflect the work and thoughts of the authors and are published herein as submitted. The publisher is not responsible for the validity of the information or for any outcomes resulting from reliance thereon.

Please use the following format to cite material from this book:

Author(s), "Title of Paper," in Nanotechnology VII, edited by lon M. Tiginyanu, Proceedings of SPIE Vol. 9519 (SPIE, Bellingham, WA, 2015) Article CID Number.

ISSN: 0277-786X

ISBN: 9781628416428

Published by

SPIE

P.O. Box 10, Bellingham, Washington 98227-0010 USA

Telephone +1 3606763290 (Pacific Time) · Fax +1 3606471445

SPIE.org

Copyright $@ 2015$, Society of Photo-Optical Instrumentation Engineers.

Copying of material in this book for internal or personal use, or for the internal or personal use of specific clients, beyond the fair use provisions granted by the U.S. Copyright Law is authorized by SPIE subject to payment of copying fees. The Transactional Reporting Service base fee for this volume is $\$ 18.00$ per article (or portion thereof), which should be paid directly to the Copyright Clearance Center (CCC), 222 Rosewood Drive, Danvers, MA 01923. Payment may also be made electronically through CCC Online at copyright.com. Other copying for republication, resale, advertising or promotion, or any form of systematic or multiple reproduction of any material in this book is prohibited except with permission in writing from the publisher. The CCC fee code is 0277-786X/15/\$18.00.

Printed in the United States of America.

Publication of record for individual papers is online in the SPIE Digital Library.

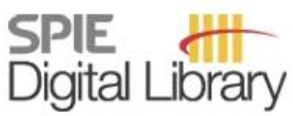

SPIEDigitalLibrary.org

Paper Numbering: Proceedings of SPIE follow an e-First publication model, with papers published first online and then in print. Papers are published as they are submitted and meet publication criteria. A unique citation identifier (CID) number is assigned to each article at the time of the first publication. Utilization of CIDs allows articles to be fully citable as soon as they are published online, and connects the same identifier to all online, print, and electronic versions of the publication. SPIE uses a six-digit CID article numbering system in which:

- The first four digits correspond to the SPIE volume number.

- The last two digits indicate publication order within the volume using a Base 36 numbering system employing both numerals and letters. These two-number sets start with $00,01,02,03,04$, $05,06,07,08,09,0 A, 0 B \ldots$. 0Z, followed by 10-1Z, 20-2Z, etc.

The CID Number appears on each page of the manuscript. The complete citation is used on the first page, and an abbreviated version on subsequent pages. the six-digit CID number. 


\title{
Contents
}

\author{
$\checkmark \quad$ Authors \\ vii Conference Committee \\ ix Measuring life: sensors and analytics for precision medicine (Plenary Paper) [95 18-502]
}

\section{NANOPHOTONICS AND PLASMONICS}

951903 ALD-tuned titanium dioxide nanophotonics [9519-2]

951904 Fabrication of photonic crystal circuits based on GaN ultrathin membranes by maskless lithography [9519-3]

QUANTUM DOTS, NANOCRYSTALS AND NANOWIRES

951906 Defect luminescence in oxide nanocrystals grown by laser assisted techniques [9519-6]

\section{APPLICATIONS IN NANO-BIOMEDICINE}

$95190 \mathrm{O}$ Optical detection of two-color-fluorophore barcode for nanopore DNA sensing [9519-16]

$9519 \mathrm{OH} \quad$ Complexation of porphyrins with nanoparticles of zeolite [9519-39]

9519 Ol Oxide-bioceramic coatings obtained on titanium items by the induction heat treatment and modified with hydroxyapatite nanoparticles [9519-18]

\section{MICROFABRICATION}

9519 OK Metal silicide/Si thin-film Schottky-diode bolometers [9519-20]

9519 OM A 2D nanoparticle sorter: towards an on-chip quantification and full characterization of nanoparticles [9519-22]

$95190 \mathrm{~N} \quad \mathrm{C}-\mathrm{IOP} / \mathrm{NiO} / \mathrm{Ni}_{7} \mathrm{~S}_{6}$ composite with the inverse opal lattice as an electrode for supercapacitors [9519-23]

\section{POSTER SESSION}

9519 OT Novel nanoplasmonic biosensor integrated in a microfluidic channel [9519-17] 
9519 OW Generation-recombination processes in InGaAs/GaAs heterostructures with onedimensional nanostructures [9519-36]

9519 0X Reduced QCSE in InGaN-based LEDs by patterned sapphire substrates with enlarging the diameter of hexagonal hole [9519-37]

$95190 Z$ Spectral and dielectric properties of nematic liquid crystal doped semiconductor quantum dots CdSe/ZnS [9519-40]

951910 Mathematical modeling of sustainability of porous $\mathrm{Al}_{2} \mathrm{O}_{3}$ growth during two-stage anodization process [9519-41]

951911 An analytical model of multi-particle electric double-layer interaction between identical spherical colloid nanoparticles [9519-42]

951915 Atomic layer deposition of $\mathrm{Al}_{2} \mathrm{O}_{3}$ on $\mathrm{NF}_{3}$-pre-treated graphene [9519-46]

951917 Production of porous oxide coatings with ultrafine crystalline structure on medical implants fabricated from alloy $12 \mathrm{Cr} 18 \mathrm{Ni9Ti}$ [9519-48]

951918 Electrodynamic properties of the nanocarbon/polymer composites with aligned by magnetic field secondary non-conductive component [9519-49]

951919 Light absorption of cylindrical quantum dot with Morse potential in the presence of parallel electrical and magnetic fields [9519-50] 
Proc. of SPIE Vol. $9519951901-6$

Downloaded From: https://www.spiedigitallibrary.org/conference-proceedings-of-spie on 26 Apr 2023 Terms of Use: https://www.spiedigitallibrary.org/terms-of-use 


\section{Conference Committee}

Symposium Chair

Ulrich Schmid, Technische Universität Wien (Austria)

Symposium Co-chairs

Thomas Becker, EADS Deutschland GmbH (Germany) and nta Isny (Germany)

Jacopo Iannacci, Fondazione Bruno Kessler (Italy)

Symposium Local Co-chair

Carles Cané, Centre Nacional de Microelectrónica (Spain)

Conference Chair

Ion M. Tiginyanu, Academy of Sciences of Moldova (Moldova)

Conference Co-chairs

Rainer Adelung, Christian-Albrechts-Universität zu Kiel (Germany) Hidenori Mimura, Shizuoka University (Japan)

Conference Programme Committee

Adrian Bachtold, ICFO - Institut de Ciències Fotòniques (Spain)

Necmi Biyikli, Bilkent University (Turkey)

Nicolas Grandjean, École Polytechnique Fédérale de Lausanne (Switzerland)

Jürgen Gutowski, Universität Bremen (Germany)

Roger A. Lewis, University of Wollongong (Australia)

Jan Linnros, Royal Institute of Technology (Sweden)

Teresa Monteiro, Universidade de Aveiro (Portugal)

Hadis Morkoç, Virginia Commonwealth University (United States)

Thierry Pauporté, École Nationale Supérieure de Chimie de Paris (France)

lonel V. Vlad, The Romanian Academy (Romania)

Vladimir A. Yuryev, A. M. Prokhorov General Physics Institute (Russian Federation)

Anatoly V. Zayats, King's College London (United Kingdom) 


\section{Session Chairs}

Monday Plenary Session

Ulrich Schmid, Technische Universität Wien (Austria)

1 Nanophotonics and Plasmonics

Ion M. Tiginyanu, Academy of Sciences of Moldova (Moldova)

2 Quantum Dots, Nanocrystals and Nanowires

Yogendra K. Mishra, Christian-Albrechts-Universität zU Kiel (Germany)

3 Aerographite, Graphene, Carbon Nanotubes

Hidenori Mimura, University of Shizuoka (Japan)

Tuesday Plenary Session

Sander van den Driesche, Universität Bremen (Germany)

Ion M. Tiginyanu, Academy of Sciences of Moldova (Moldova)

4 Applications in Nano-Biomedicine

Andrei Sarua, University of Bristol (United Kingdom)

5 Microfabrication

Necmi Biyikli, Bilkent University (Turkey)

Wednesday Plenary Session

José Luis Sánchez-Rojas, Universidad de Castilla-La Mancha (Spain) Jacopo Iannacci, Fondazione Bruno Kessler (Italy)

6 Synthesis, Surface Modification, Nano-Devices and Reliability

Teresa Monteiro, Universidade de Aveiro (Portugal) 